\title{
Etiology and Real-Time Polymerase Chain Reaction-Based Detection of Gremmeniella- and Phomopsis-Associated Disease in Norway Spruce Seedlings
}

\author{
Isabella Børja, Halvor Solheim, Ari M. Hietala, and Carl Gunnar Fossdal
}

Norwegian Forest and Landscape Institute, P.O. Box 115, 1431 Ås, Norway. Accepted for publication 7 July 2006.

\begin{abstract}
Børja, I., Solheim, H., Hietala, A. M., and Fossdal, C. G. 2006. Etiology and real-time polymerase chain reaction-based detection of Gremmeniella- and Phomopsis-associated disease in Norway spruce seedlings. Phytopathology 96:1305-1314.

In spring 2002, an unusual disease outburst was recorded on Norway spruce seedlings in southeast Norway. Extensive damage was recorded on 1- and 2-year-old Norway spruce seedlings that either had wintered in nursery cold storage or had been planted out in autumn 2001. The damage was characterized by leader shoot dieback and stem necroses on the upper or lower part of the shoot from 2001. Gremmeniella abietina and a Phomopsis sp. frequently were isolated from the diseased seedlings. Internal transcribed spacer (ITS) ribosomal (r)DNA sequence analysis and

tree type (LTT) ecotype of the European race of G. abietina var. abietina, and inoculation tests confirmed their pathogenicity on Norway spruce. Based on ITS rDNA sequence analysis, the Phomopsis strains associated with diseased seedlings did not represent any characterized Phomopsis spp. associated with conifers. The Phomopsis sp. was not pathogenic in inoculation tests, indicating that it may be a secondary colonizer. ITS-based real-time polymerase chain reaction assays were developed in order to detect and quantify G. abietina and Phomopsis in the nursery stock. We describe here the G. abietina-associated shoot dieback symptoms on Norway spruce seedlings and conclude that the unusual disease outburst likely was related to the G. abietina var. abietina epidemic caused by the LTT on large Scots pines in 2001.
\end{abstract} random amplified microsatellites profiling indicated that the $G$. abietina strains associated with diseased nursery seedlings belonged to the large-
Additional keywords: Picea abies.
Gremmeniella abietina (Lagerb.) M. Morelet is one of the most serious pathogens on pines in the Northern hemisphere. It causes a range of symptoms known as the Brunchorstia dieback or Scleroderris canker. G. abietina comprises two described varieties: var. abietina associated with a number of conifers and with a large geographic distribution area, and var. balsamea known only from Quebec, Canada, where it is associated with Abies balsamea, Picea glauca, and P. mariana (25). As reviewed by Hamelin and Rail (12), G. abietina var. abietina, based on morphological, serological, and genetic studies, has been divided into North American, Asian, and European races. The European race of G. abietina var. abietina consists of two ecotypes named the "small-tree type" (STT) and the "large-tree type" (LTT) (16), also previously described as biotypes A and B, respectively (30). Based on pairing tests, STT and LTT are regarded as genetically isolated (32). The LTT is most common in 15- to 40-year-old Scots pine (Pinus sylvestris L.) trees in southern Scandinavia and Finland $(15,31)$, where it causes dieback of current-year shoots in the entire crown. The STT occurs on young Scots pine trees in northern Scandinavia and at higher elevations in the south, where it causes perennial cankers on the parts of the tree covered by a lasting snow layer during the winter (19).

Besides pines, G. abietina also may attack Norway spruce (Picea abies (L.) Karst.), where the infection occurs mainly on the previous year's leader shoot and results in stem girdling and top dying $(20,28)$. During the outbreaks in the southernmost part of Norway in the early 1980s, G. abietina damaged Norway

Corresponding author: I. Børja; E-mail address: isabella.borja@ skogoglandskap.no

DOI: 10.1094/PHYTO-96-1305

(c) 2006 The American Phytopathological Society spruce trees and saplings grown as the understorey below Scots pine $(2,28)$.

The symptoms of Gremmeniella spp. damage on trees (here defined as having a diameter $>10 \mathrm{~cm}$ at breast height) differ from those on saplings ( $>1 \mathrm{~m}$ tall) and seedlings $(<1 \mathrm{~m}$ tall). On Scots pine seedlings, damage caused by $G$. abietina can be identified readily due to the characteristic umbrella-like folding of needles on the infected leader shoot $(4,22)$. Regarding Norway spruce seedlings, there are no reports describing Gremmeniella infection on seedlings while still in nursery production ( $\leq 2$ years old). Barklund and Hellgren (1) explained this by a long latent period after the infection and reported that shoot dieback symptoms on seedlings usually develop after they have been planted out. The symptoms at this stage are described as being similar to shoot dieback caused by Sirococcus conigenus (DC.) P. F. Cannon \& Minter (5).

In spring 2001, a devastating epidemic of G. abietina occurred on large Scots pines in southeastern Norway and in adjacent parts of Sweden (29). The autumn of 2000 had been mild and wet with a sudden onset of frost periods, and the fluctuation between mild and cold periods continued throughout the whole winter. These climatic conditions are known to be conducive to Gremmeniella infection (7,21). The following spring (2002), a great number of 2-year-old Norway spruce seedlings, which had wintered in nursery cold storage or had been planted out in the autumn of 2001, showed wilting top shoots and symptoms of various degrees of shoot dieback. When surveying the heavily affected plant nurseries, 1-year-old seedlings showed similar symptoms, but to a lesser extent. In the commercial evaluation of 115 thousand seedlings originating from the nursery with the greatest damage, $34 \%$ of Norway spruce seedlings had to be discarded due to shoot dieback, and $13 \%$ of the seedlings eventually died after planting. 
On damaged seedlings, two distinct types of necroses were observed on the 2001 shoots, resulting in stem girdling and shoot dieback. G. abietina and a Phomopsis sp. were recovered from the necrotic tissue. The objectives of this work were to (i) describe the disease on Norway spruce seedlings, (ii) further determine the pathogenicity of the associated $G$. abietina and Phomopsis sp. in vivo and in vitro, (iii) identify these strains at species or ecotype level, and (iv) develop real-time polymerase chain reaction (PCR) assays that can be used for rapid diagnosis of diseased seedlings.

\section{MATERIALS AND METHODS}

Plant material and fungal isolation. In spring and summer 2002, 2-year-old Norway spruce seedlings were collected mainly from the two most affected nurseries in southeastern Norway (Prestebakke Nursery at Kornsjø in Østfold County and Telemark Nursery at Gvarv in Telemark County). In addition, Norway spruce seedlings from nurseries that did not report on similar problems were collected for inspection (Table 1). The seedlings were collected either immediately after the cold storage or from the field after having been planted out in the previous autumn. Both diseased and healthy looking plants were collected for inspection and isolation of fungi. Plants were dissected in order to trace the initial infection court, and the length of the second-year shoot (year 2001), the length of the necrosis, and the distance from the lower edge of the necrosis to the 2000-01 stem node were measured.

Fungal isolations were made from the margins of necrotic lesions by placing host tissue pieces ( 2 by 2 by $3 \mathrm{~mm}$ ) on malt agar (1.25\% malt and 2\% agar). After an incubation period of 3 to 5 weeks at $21^{\circ} \mathrm{C}$ in the dark, the fungal colonies were subcultured onto fresh media.

Pathogenicity tests. The pathogenicity test in vitro was a modification of a bioassay described by Galaaen and Venn (10). Three isolates each of $G$. abietina (2002-48/2, 2002-26/2, and 200247/1) and a Phomopsis sp. (2002-53/3, 2002-117/3, and 2002$62 / 1$ ), characterized in Table 2 , were tested for their ability to cause damage on plant material. In addition, two isolates of S. conigenus (2000-58/2 and 2000-54/3, deposited in the fungal culture collection of the Norwegian Forest and Landscape Institute), a pathogen causing a similar shoot dieback on spruce seedlings, were included in the pathogenicity tests. Ten needles, detached from aseptically grown 5-week-old Norway spruce seedlings, were placed in front of an advancing mycelial zone growing in a petri dish with malt agar medium. Three petri dish replicates were prepared for each fungal strain tested, while needles placed on malt agar without fungus served as controls. The petri dishes were incubated in the darkness at $19 \pm 2^{\circ} \mathrm{C}$. After $1,2,3,4,5,7$, and 10 days, each needle was examined under stereomicroscope and the relative tissue damage (percentage of discoloration) was estimated visually. The time required for a strain to kill $50 \%$ of the needles was determined.

To determine the pathogenicity of the isolated fungi in vivo, healthy, apparently uniform looking 1- and 2-year-old Norway spruce seedlings were inoculated with the same fungal strains as in the pathogenicity test with needles. Ten seedlings of both ages were inoculated with each strain by placing a piece of malt-agargrown fungal mycelium $\left(\approx 1 \mathrm{~mm}^{3}\right)$ inside a 2 -mm-long incision made with a scalpel in the bark in the middle half of the stem, and sealing the wound with parafilm. Control seedlings were treated similarly with malt agar only. Seedlings then were placed in containers and incubated in a climatic chamber, where cold storage conditions ( 2 to $5^{\circ} \mathrm{C}, 80 \%$ humidity, and darkness) were simulated. The extent of the necroses was measured 18 weeks later.

Outplanted symptom-bearing seedlings. In order to follow the further development of diseased seedlings, 36 diseased, 1year-old Norway spruce seedlings from the affected Prestebakke nursery were planted out in the experimental garden of the Norwegian Forest and Landscape Institute. After outplanting in summer 2002, the seedlings were observed regularly during the following growing seasons for their condition, and for the presence of G. abietina and Phomopsis sp. fruit bodies. The experiment was ended in January 2005.

Internal transcribed spacer ribosomal DNA sequence analysis and random amplified microsatellites PCR. The Grem-

TABLE 1. Characteristics of Norway spruce seedlings with upper- and lower-stem necroses, and frequency of Gremmeniella abietina and a Phomopsis sp. isolated from the necroses

\begin{tabular}{|c|c|c|c|c|c|}
\hline \multirow[b]{2}{*}{ Isolation date $^{\mathrm{a}}$} & \multirow[b]{2}{*}{$\mathrm{Age}^{\mathrm{b}}$} & \multirow[b]{2}{*}{ Locality in Norway } & \multirow[b]{2}{*}{$n^{\mathrm{c}}$} & \multicolumn{2}{|c|}{ Fungi isolated (\%) } \\
\hline & & & & G. abietina & Phomopsis sp. \\
\hline \multicolumn{6}{|l|}{ Upper-stem necroses } \\
\hline 24 April 2002 & A & Prestebakke, Østfold & $6 / 6$ & 83 & 0 \\
\hline 10 May 2002 & B & Prestebakke, Østfold & $5 / 3$ & 66 & 0 \\
\hline 23 May 2002 & B & Rakkestad, Østfold & $3 / 3$ & 100 & 0 \\
\hline 23 May 2002 & B & Hokksund, Buskerud & $8 / 4$ & 75 & 0 \\
\hline 20 June 2002 & A & Granli, Hedmark & $7 / 7$ & 43 & 29 \\
\hline 23 June 2002 & A & Lyngdal, Vest-Agder & $4 / 4$ & 0 & 100 \\
\hline 23 June 2002 & A & Lyngdal, Vest-Agder & $5 / 5$ & 20 & 40 \\
\hline \multicolumn{6}{|l|}{ Lower-stem necroses } \\
\hline 26 April 2002 & A & Biri, Oppland & $4 / 4$ & 0 & 100 \\
\hline 30 April 2002 & $\mathrm{~B}$ & Andebu, Vestfold & $5 / 5$ & 0 & 80 \\
\hline 08 May 2002 & B & Andebu, Vestfold & $14 / 5$ & 0 & 100 \\
\hline 23 May 2002 & B & Larvik, Vestfold & $10 / 10$ & 0 & 20 \\
\hline 29 May 2002 & $\mathrm{~A}$ & Gvarv, Telemark & $24 / 6$ & 0 & 17 \\
\hline 03 June 2002 & B & Gvarv, Telemark & $3 / 3$ & 0 & 0 \\
\hline 10 July 2002 & B & Nøss, Oppland & $5 / 5$ & 0 & 20 \\
\hline 16 December 2002 & A & Alstahaug, Nordland & $17 / 11$ & 0 & 100 \\
\hline
\end{tabular}

${ }^{a}$ Seedlings with upper- and lower-stem necroses.

${ }^{\mathrm{b}} \mathrm{A}=2$-year-old seedlings from cold storage and $\mathrm{B}=2$-year-old seedlings, planted out.

c Total number of seedlings examined/number of seedlings from which isolation was made. 
meniella and Phomopsis isolates processed for molecular characterization are shown in Table 2. In addition, we sequenced the following four Diaporthe (teleomorph genus of Phomopsis) and Phomopsis strains isolated from conifers and deposited at the Centraalbureau voor Schimmelcultures (CBS): Diaporthe conorum (CBS186-37), D. conorum (CBS 199-39), Phomopsis conorum (CBS 587-79), and $P$. juniperivora (CBS 186-27). To obtain mycelia for DNA isolation, the fungal strains were grown on cellophane-coated malt (1.25\% malt and 2\% agar) and V8 juice agar (20\% V8 and 2\% agar) (Campbell Grocery Products LTD, Norfolk, UK), and the mycelia harvested were ground with a pestle in liquid $\mathrm{N}_{2}$-chilled mortars. DNA isolation was performed using the Plant DNA Mini Isolation Kit (Qiagen, Hilden, Germany) according to the manufacturer's instructions.

For internal transcribed spacer (ITS) ribosomal (r)DNA sequence analysis, 30 cycles (annealing temperature $57^{\circ} \mathrm{C}$ ) of PCR amplification were carried out with a $200-n M$ concentration of the ITS1 and ITS4 primers (33) in 50- $\mu$ l reaction volumes using HotStarTaq DNA Polymerase according to the manufacturer's instructions (Qiagen). After gel electrophoresis, the PCR products were purified with QIAquick Gel Extraction Kit and QIAquick PCR purification Kit (Qiagen), ligated into a cloning vector (pDrive Cloning vector of Qiagen PCR Cloning ${ }^{\text {plus }}$ Kit), and transformed into Qiagen EZ Competent Cells. For sequencing, plasmid DNA was isolated and purified using QIAprep Miniprep (Qiagen). Three distinct colonies were sequenced with -21 M13 and M13 reverse primers in both directions on an ABI PRISM 3100 Genetic Analyzer (Applied Biosystems, Foster City, CA) for each isolate. The alignments of complementary strands and the similarity studies within sequenced samples were determined with the Seqman software (Lasergene, DNASTAR Inc., Madison, WI). Similarities to known ITS regions were performed with the BLAST search engines of the National Center for Biotechnology Information (NCBI) GenBank (Bethesda, MD) and multiple se- quence alignments were performed with Clustal W of Kyoto University Informatics Center, Japan.

The random amplified microsatellite (RAMS) technique was used to further characterize the Gremmeniella and Phomopsis isolates. The PCR reactions were carried out in the reaction conditions recommended by the manufacturer of the HotStarTaq DNA Polymerase using $2 \mu \mathrm{M}$ concentrations of the degenerate ACA and CCA primers described by Hantula and Müller (14). The PCR cycling parameters also were as described in that study. Amplification products were separated by gel electrophoresis in $1.5 \%$ agarose gels using Tris-acetate-EDTA running buffer and visualized under UV light after ethidium bromide staining.

Quantification of host and pathogen by real-time PCR. To allow rapid and high throughput detection of G. abietina and the Phomopsis sp. in diseased seedlings, we developed real-time PCR assays for detecting and quantifying their DNA. The assays were used for analyzing diseased Norway spruce seedlings sent from the forest nurseries during the summers of 2003 and 2004. Stem sections ( $5 \mathrm{~mm}$ long) were taken from the middle and the margin of necrotic stem lesions and from the neighboring healthy tissue. DNA isolation was performed using Plant DNA Mini Isolation Kit (Qiagen) according to the manufacturer's instructions, and using a 50- $\mu$ l elution volume.

The real-time PCR primers used for monitoring G. abietina and Phomopsis sp. colonization in infected seedlings were designed with the Primer Express software 1.5a provided with Applied Biosystems real-time quantitative PCR systems (Applied Biosystems) by employing conserved and species-specific sequence areas in the ITS rDNA gene cluster. The forward primer 5'-CACCCGTGCCTATATTACTCTGTTG-3', reverse primer 5'-TATAGTACTCAGACGGTAAATAATTCATAGGTT-3', and a VIClabeled probe 5'-TTCCCGGGCCTCAACCCCC-3' were selected for real-time PCR quantification of G. abietina. For quantification of the Phomopsis sp., the forward primer 5'-GCACCCAG-

TABLE 2. Gremmeniella abietina and Phomopsis strains processed for molecular characterization

\begin{tabular}{|c|c|c|c|c|c|c|}
\hline Species & Strain $^{\mathrm{a}}$ & Accession no. ${ }^{b}$ & Host & $\mathrm{Age}^{\mathrm{c}}$ & Locality in Norway & Note $^{\mathrm{d}}$ \\
\hline G. abietina & 1974-46/1 & Ns & Pinus sylvestris & Sapling & Malmmyra, Rendalen, Hedmark & STT \\
\hline G. abietina & $1975-32 / 1$ & DQ445885 & P. sylvestris & Sapling & Folldal verk, Folldal, Hedmark & STT \\
\hline G. abietina & $2002-20 / 4$ & $\mathrm{Ns}$ & P. sylvestris & Sapling & Øyerberget, Kongsvinger, Hedmark & LTT \\
\hline G. abietina & $2002-47 / 1$ & DQ116556 & P. sylvestris & Tree & Kongsvinger, Hedmark & LTT \\
\hline G. abietina & $1985-393 / 16 / 1$ & DQ445884 & P. contorta & Sapling & Matrand, Eidskog, Hedmark & LTT \\
\hline G. abietina & $1985-393 / 19 / 1$ & Ns & P. contorta & Sapling & Matrand, Eidskog, Hedmark & LTT \\
\hline G. abietina & 1988-306/1 & Ns & P. contorta & Sapling & Malmmyra, Rendalen, Hedmark & STT \\
\hline G. abietina & $1988-307 / 3$ & DQ445883 & P. contorta & Sapling & Malmmyra, Rendalen, Hedmark & STT \\
\hline G. abietina & $1966-163 / 2$ & Ns & P. abies & Sapling & Holmegil, Aremark, Østfold & LTT \\
\hline G. abietina & $1985-111 / 6$ & Ns & P. abies & Sapling & Viblemo, Audnedal, Vest-Agder & LTT \\
\hline G. abietina & $2002-107 / 2$ & DQ445882 & P. abies & Seedling & Granli nursery, Granli, Hedmark & LTT \\
\hline G. abietina & $2002-109 / 4$ & DQ445881 & P. abies & Seedling & Granli nursery, Granli, Hedmark & LTT \\
\hline G. abietina & $2002-124 / 1$ & Ns & P. abies & Seedling & Lyngdal nursery, Lyngdal, Vest-Agder & LTT \\
\hline G. abietina & $2002-26 / 2$ & DQ116557 & P. abies & Seedling & Prestebakke nursery, Kornsjø, Østfold & LTT \\
\hline G. abietina & $2002-29 / 3$ & DQ116559 & P. abies & Seedling & Prestebakke nursery, Kornsjø, Østfold & LTT \\
\hline G. abietina & $2002-4 / 4$ & DQ445880 & P. abies & Seedling & Prestebakke nursery, Kornsjø, Østfold & LTT \\
\hline G. abietina & $2002-48 / 2$ & DQ116558 & P. abies & Seedling & Rakkestad, Østfold & LTT \\
\hline G. abietina & $2002-79 / 2$ & Ns & P. abies & Seedling & Vestfold & LTT \\
\hline Phomopsis sp. & $2002-18 / 1$ & DQ445887 & P. abies & Seedling & Andebu, Vestfold & $\ldots$ \\
\hline Phomopsis sp. & $2002-34 / 3$ & Ns & P. abies & Seedling & Andebu, Vestfold & $\ldots$ \\
\hline Phomopsis sp. & $2002-51 / 3$ & Ns & P. abies & Seedling & Brunlanes, Larvik, Vestfold & $\ldots$ \\
\hline Phomopsis sp. & $2002-53 / 3$ & DQ445888 & P. abies & Seedling & Brunlanes, Larvik, Vestfold & $\ldots$ \\
\hline Phomopsis sp. & $2002-62 / 1$ & DQ116550 & P. abies & Seedling & Telemark nursery, Gvarv, Telemark & $\ldots$ \\
\hline Phomopsis sp. & $2002-73 / 3$ & Ns & P. abies & Seedling & Telemark nursery, Gvarv, Telemark & $\ldots$ \\
\hline Phomopsis sp. & $2002-105 / 4$ & Ns & P. abies & Seedling & Granli nursery, Granli, Hedmark & $\ldots$ \\
\hline Phomopsis sp. & $2002-113 / 2$ & DQ445886 & P. abies & Seedling & Granli nursery, Granli, Hedmark & $\ldots$ \\
\hline Phomopsis sp. & $2002-117 / 3$ & DQ445890 & P. abies & Seedling & Granli nursery, Granli, Hedmark & $\ldots$ \\
\hline Phomopsis sp. & $2002-120 / 1$ & DQ445889 & P. abies & Seedling & Lyngdal nursery, Lyngdal, Vest-Agder & $\ldots$ \\
\hline Phomopsis sp. & $2002-131 / 2$ & $\mathrm{Ns}$ & P. abies & Seedling & Nøss, Nordre Land, Oppland & $\ldots$ \\
\hline Phomopsis sp. & $2002-132 / 3$ & Ns & P. abies & Seedling & Nøss, Nordre Land, Oppland & $\ldots$ \\
\hline
\end{tabular}

a All strains are deposited at the culture collection of Norwegian Forest Research Institute and are available at request.

b National Center for Biotechnology Information GenBank Sequence Database accession numbers; Ns = not sequenced.

c Seedlings $<1 \mathrm{~m}$ tall, saplings $>1 \mathrm{~m}$ tall, and tree $>10 \mathrm{~cm}$ in diameter at breast height.

d STT $=$ small-tree-type reference and LTT $=$ large-tree-type reference. 
AAACCCTTTGTG-3', reverse primer 5'-AAGAGTTGACTTGGCCGCC-3', and a VIC-labeled probe 5'-CGGTAACGAGGAGCAGCCCGC-3' were selected.

Co-precipitation of compounds that inhibit PCR confounds molecular analyses of environmental samples by producing false negative results (34). To eliminate false negatives, Norway spruce DNA was used as an endogenous reference in analyzed samples from infected nursery seedlings, and estimated by using the polyubiquitin primer/probe set previously described (17). To investigate the specificity of the primer/probe sets used, the following ascomycetes, related to G. abietina or the Phomopsis sp. and commonly associated with shoots of Norway spruce, $S$. conigenus (strains 2000-54/3 and 2000-58/2), Botrytis cinerea (strain 1983145/1), Herpotrichia juniperi (strain 1973-53), Rhizosphaera kalkhoffii (strain 1997-1/6), Epicoccum nigrum (strain 19591898/1/1), Nectria fuckeliana (strain 197-74), and Tiarosporella parca (strain 1991-727/28) were processed as described above for the Gremmeniella and Phomopsis strains. In addition, detection of D. conorum (CBS186-37), D. conorum (CBS 199-39), P. conorum (CBS 587-79), and $P$. juniperivora (CBS 186-27) DNA by the Phomopsis primer/probe set was examined. The real-time PCR detection of DNA of Norway spruce, G. abietina, and the Phomopsis sp. was performed with TaqMan Universal PCR Master Mix (P/N 4304437; Applied Biosystems). Primer and probe concentrations of 150 and $330 \mathrm{nM}$, respectively, were used for detecting DNA of Norway spruce (17). To optimize primer/probe concentrations for quantitative detection of G. abietina and the Phomopsis sp., several primer and probe concentrations were tested by using the corresponding standard curve samples (described below) as templates. For both fungi, a primer concentration of $300 \mathrm{nM}$ and a probe concentration of $400 \mathrm{nM}$ were chosen because they showed a stable amplification efficiency over the concentration range used in the corresponding standard curve. All PCR reactions were performed under singleplex conditions.

To construct standard curves for quantification of Norway spruce and pathogen DNA, DNA isolated from a healthy control seedling and from pure cultures of G. abietina and the Phomopsis sp. were quantified by using a Versafluor fluorometer (Bio-Rad, Hercules, CA) and a PicoGreen DNA quantification kit (Molecular Probes, Eugene, OR), and then pooled together in known concentrations. The host DNA standard curve samples $(100,000$, $10,000,1,000$, and $100 \mathrm{pg}$ of Norway spruce DNA) all were spiked with 1,000 pg of G. abietina and 1,000 pg of the Phomopsis sp. DNA. The Gremmeniella DNA standard curve samples $(1,000,100,10,1$, and $0.1 \mathrm{pg}$ of $G$. abietina DNA) all were spiked with 1,000 pg of Norway spruce and 1,000 pg of Phomopsis sp. DNA. The Phomopsis DNA standard curve samples $(1,000$, $100,10,1$, and $0.1 \mathrm{pg}$ of Phomopsis sp. DNA) all were spiked with 1,000 pg of Norway spruce and 1,000 pg of G. abietina DNA. To ensure that the signals from the experimental samples fell within the standard curves, and to investigate the presence of compounds inhibitory to PCR, 4-log dilution series were prepared for experimental samples. As a template, $3 \mu$ of the DNA solution for both experimental and standard curve samples were used for each $25-\mu \mathrm{l}$ PCR reaction. Each reaction was repeated twice. PCR cycling parameters were $95^{\circ} \mathrm{C}$ for $10 \mathrm{~min}$, followed by 40 cycles of $95^{\circ} \mathrm{C}$ for $15 \mathrm{~s}$ and $60^{\circ} \mathrm{C}$ for $1 \mathrm{~min}$. Fluorescence emissions were detected with an ABI Prism 7700 (Applied Biosystems). Data acquisition and analysis were performed with the Sequence Detection System software package (1.7a; Applied Biosystems). The amounts of Norway spruce and fungal DNA in the samples were calculated from the respective standard curves by using critical threshold $(\mathrm{Ct})$-based calculation procedures. Genomic DNA from healthy Norway spruce and from included reference fungi was used as a negative control for the fungal primer/probe sets, while fungal DNA served as negative controls for the host primer/ probe set. To further test the function of the Gremmeniella and
Phomopsis primer/probe sets, we spiked DNA obtained from selected seedlings from which Gremmeniella or Phomopsis spp. had been isolated or detected by real-time PCR. The former was spiked with $500 \mathrm{pg}$ of the Phomopsis sp. DNA, whereas the latter was spiked with $500 \mathrm{pg}$ of G. abietina DNA, and the ability of the primer/probe sets to detect and quantify the added DNA was determined.

Statistical analysis. The data for necrosis length on 1- and 2-year-old Norway spruce seedlings in the in vivo pathogenicity test were subjected to analysis of variance (ANOVA) by using one-way ANOVA (JMP; SAS institute, Cary, NC). For comparison of all pairs the Tukey-Kramer highly significant difference test was applied $(P<0.0002)$.

\section{RESULTS}

Description of disease symptoms. The symptoms on Norway spruce seedlings became visible during the spring of 2002, 1 year after the Gremmeniella epidemic on Scots pine trees. Both 1- and 2-year-old plants showed symptoms of desiccated leader shoots and had necrotic lesions on the stems of shoots from 2001 (Fig. 1A). Often, the seedlings appeared healthy and the necroses became visible only after the stem bark had been peeled off (Fig. 1B and $\mathrm{C}$ ). The first visible signs of a stem lesion were a local indentation in the bark and grayish-green foliage on the lesion area. Later, the foliage and branches distal to the lesion area became yellow and brown. Some lesions were located only on one side of the stem, whereas others ringed the whole stem, causing dieback of the shoot. Occasionally, there were two to three separate necroses on one stem. Generally, two types of necroses, upperand lower-stem necroses, could be distinguished.

Upper-stem necroses associated with G. abietina. Mean 2001 shoot length on 2-year-old seedlings with this type of necrosis was $25 \mathrm{~cm}$. Necroses on the upper stem were located a mean distance of $14.9 \mathrm{~cm}$ above the 2000-01 stem node and their average length was $4.3 \mathrm{~cm}$. The necrotic, dark-brown-colored bark was profusely impregnated with resin (Fig. 1A and C). In this area, the stem usually was girdled, the nearby needles were brown at the base, and the shoots above the necrosis were dead or dying. The edges of the necroses were sharp and distinct. In most cases, G. abietina was isolated from the advancing edge of the necrotic tissue (Table 1). G. abietina alone was isolated predominantly from seedlings sampled during April and May. In isolations performed later (June and later), a Phomopsis sp. occasionally was recovered from this type of necrosis (Table 1). These two fungi were isolated from the same batch of plants and the same type of necrosis, but never together from the same plant or the same necrosis. No other potentially pathogenic fungi were isolated from the upper-stem necroses. Most of the seedlings with upper-stem necroses yielding G. abietina originated from Prestebakke Nursery, where Scots pine trees were in the close vicinity of the nursery area.

Lower-stem necroses associated with a Phomopsis sp. Mean 2001 shoot length on 2-year-old plants with this type of necrosis was $21 \mathrm{~cm}$. The mean distance from the lower edge of the necroses to the $2000-01$ stem node was $3.9 \mathrm{~cm}$. These necroses often were located at the base of the 2001 shoot or partly at the end of the 2000 shoot. Necroses on the lower stem were lighter in color compared with the upper-stem necroses, and had a characteristic water-soaked appearance without any resin flow (Fig. 1D). The edges of the necroses were diffuse and nondistinct. Occasionally, such necroses also were found on the upper part of the 2001 shoot. The most frequently isolated fungus from these lesions was a Phomopsis sp., which was recovered in the period from April to December (Table 1). Apart from two cases where a Botrytis sp. was recovered, no other potentially pathogenic fungi were isolated from these necroses. Fruit bodies of the Phomopsis sp. developed readily on plants after storage at $+4^{\circ} \mathrm{C}$. Seedlings 
with lower-stem necroses originated mostly from Telemark Nursery, where there were no Scots pine trees in the immediate vicinity.

Pathogenicity tests. In the pathogenicity test in vitro with needles (Fig. 2), G. abietina strains killed $50 \%$ of the needle tissue within 4 to 6 days, strain 2002-48/2 being the most aggressive. One of the two included isolates of $S$. conigenus (strain 2000-58/2) caused 50\% needle damage after 7 days of incubation, whereas the other S. conigenus (strain 2000-54/3) caused the same extent of damage after 9 days. Two Phomopsis strains
(2002-62/1 and 2002-117/3) showed 50\% damage after 8 days. The Phomopsis strain 2002-53/3 showed no signs of pathogenicity 10 days after the incubation, when the experiment was ended. In contrast to the necrotic spots and shrivelling of the needles caused by $G$. abietina, needles overgrown by the Phomopsis sp. showed a uniform discoloration, but remained turgid, suggesting a different mode of interaction with needles than that by G. abietina.

In the pathogenicity test in vivo, seedlings were stored in climatic chambers for 18 weeks in the period from mid-November to the end of March. In 1-year-old seedlings, G. abietina strains

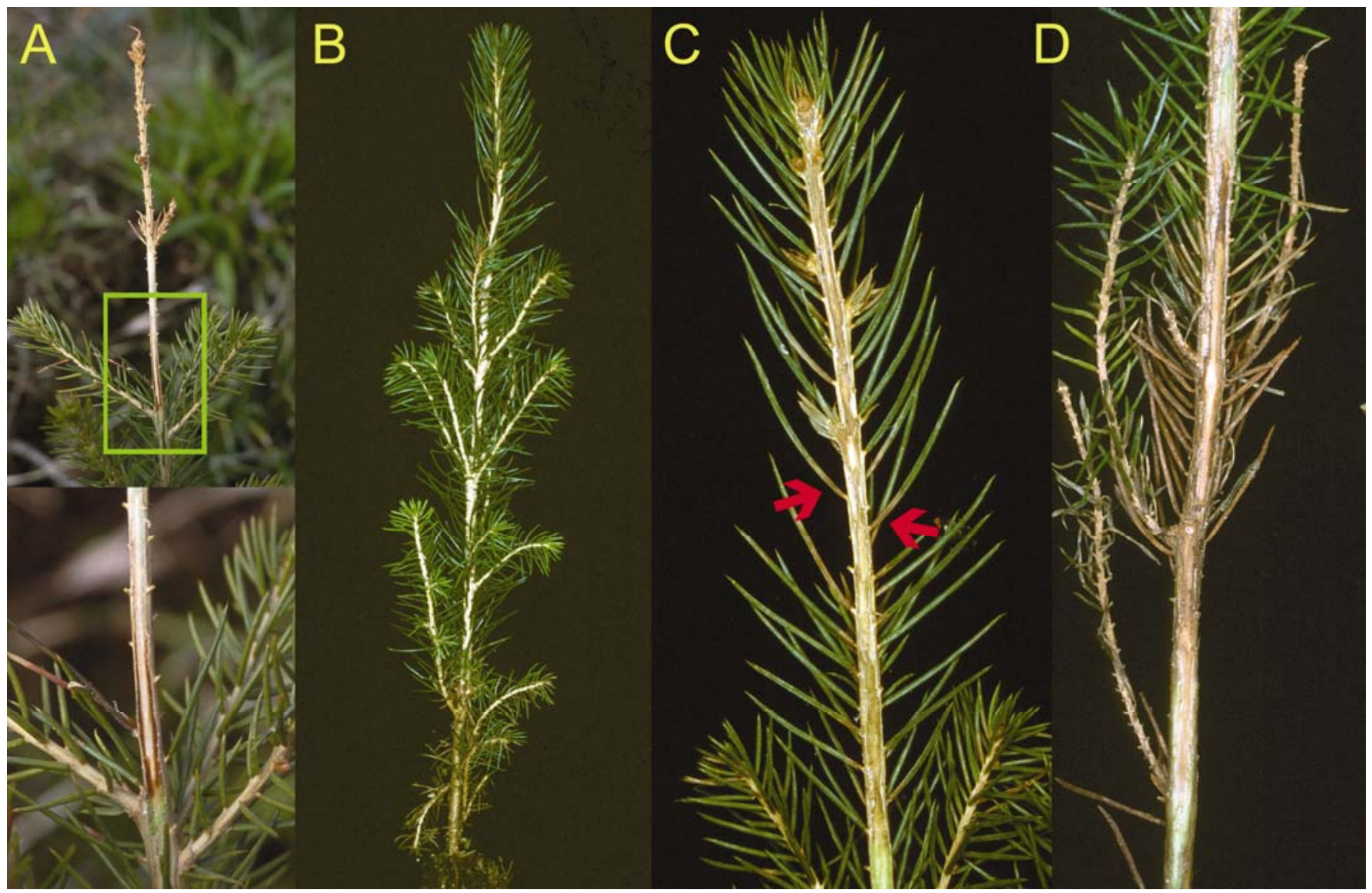

Fig. 1. Symptoms of top dieback in Norway spruce seedlings associated with Gremmeniella abietina and a Phomopsis sp. A, Typical symptom of dry leader on 2-year-old seedlings after planting out; G. abietina was isolated from the resinous necrosis (A, detail below). B, Seedling appeared to be healthy but, when bark was peeled off, extensive necrosis in the leader was revealed. C, Note also the browning of needles from the bases (arrows). D, Light-colored and water-soaked necroses from which the Phomopsis sp. was isolated usually were located close to the stem node.

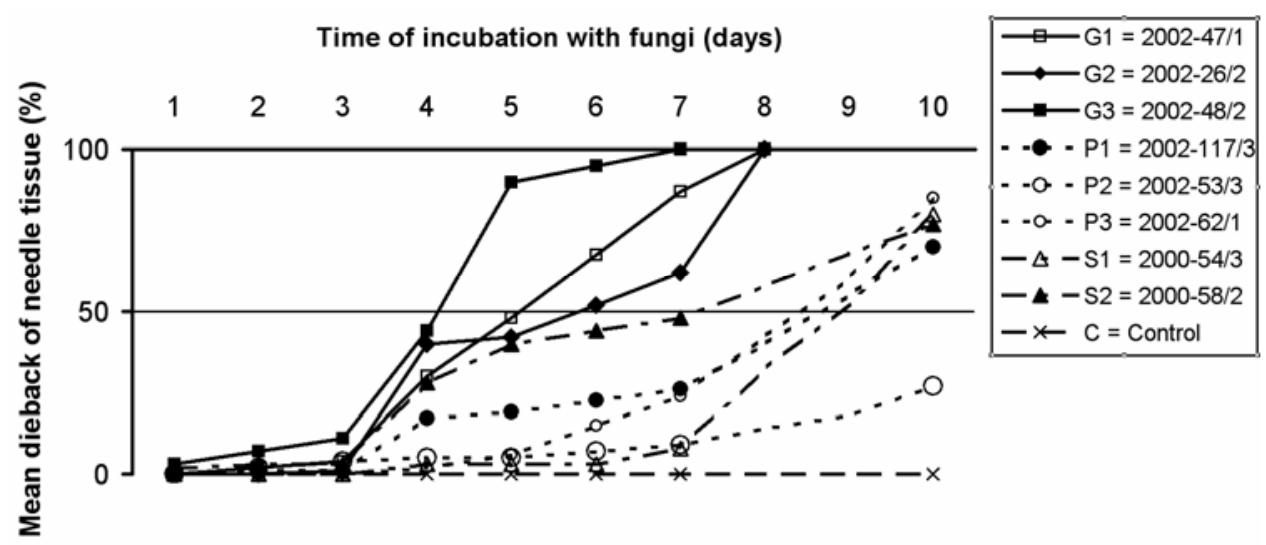

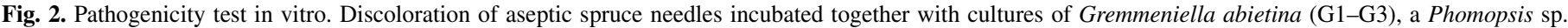

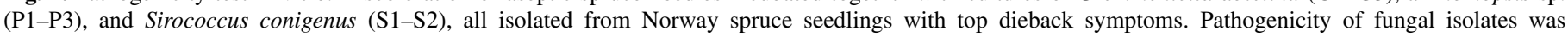
estimated as the time needed for the fungus to kill $50 \%$ of the needles. 
2002-48/2 and 2002-26/2 caused significantly longer necroses than the other strains (Fig. 3). The necroses produced by the other strains were not significantly different from the control. In 2-yearold seedlings, the longest necroses were caused by $G$. abietina strains $2002-26 / 2$ and 2002-48/2, but only G. abietina strain 2002-26/2 differed significantly from the control (Fig. 3).

Symptom-bearing seedlings in outplanted plots. In spring 2003 , at the time of the first assessment, $23 \%$ of the seedlings $(8$ of 36 seedlings) had a tendency to develop a double shoot (i.e., two side shoots were competing for dominance). At this time, four dead shoots had pycnidia of Brunchorstia pinea (P. Karst.) Höhn., the anamorph stage of G. abietina, with conidia still present. In January 2005, at the time of final harvesting, $64 \%$ of the seedlings ( 9 of 14 seedlings) had developed a double stem (unfortunately, 22 seedlings were destroyed by accident before the last evaluation; thus, only the 14 remaining seedlings were inspected at the end of the experiment). The seedlings were still alive, and showed good growth. The originally diseased leader shoots had been taken over by a new leader. Of the 14 dead shoots collected at the last inspection, 4 had old, empty pycnidia still present, whereas 10 had only visible scars after pycnidia. No apothecia were observed in any seedling.

Molecular characterization of isolates of $G$. abietina and the Phomopsis sp. The ITS rDNA sequences obtained from G. abietina isolates from Norway spruce seedlings, deposited as GenBank accession nos. DQ116556 to DQ116558 and DQ445881 to DQ445885, were identical to each other (not shown). In BLAST analysis against the NCBI GenBank Sequence Databases, these sequences showed $100 \%$ sequence identity to the European race of G. abietina. The ITS rDNA sequences of the included reference strains of LTT and STT were indistinguishable from each other and from those obtained from Norway spruce seedlings, indicating that the ITS rDNA sequence cannot be used to distinguish between the ecotypes. The RAMS-ACA and RAMS-

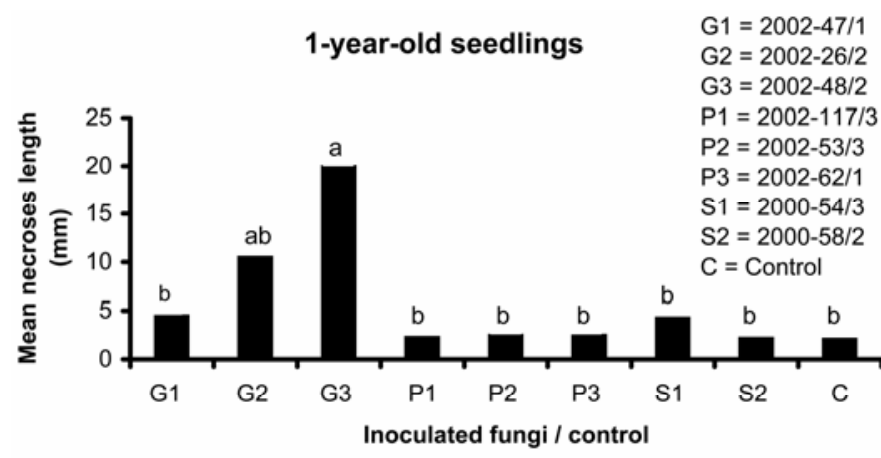

2-year-old seedlings

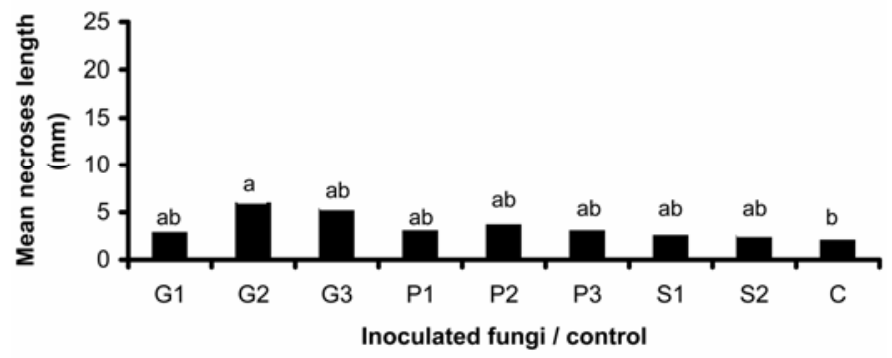

Fig. 3. Length of necroses in 1- and 2-year-old Norway spruce seedlings 18 weeks after inoculation with different isolates of Gremmeniella abietina (G1-G3), a Phomopsis sp. (P1-P3), Sirococcus conigenus (S1-S2), and the control (C). Different letters indicate significant differences between treatments (Tukey's highly significant difference test, $P<0.0001$ and 0.0002 for 1 - and 2-year-old seedlings, respectively; $n=180$ ).
CCA banding patterns were identical among the G. abietina isolates from Norway spruce seedlings, whereas the included reference strains of LTT and STT showed type-specific banding patterns (Fig. 4A and B). The assay confirmed that all the G. abietina isolates from Norway spruce seedlings belonged to the LTT, because their banding patterns were identical to those from the reference strains of the type. For example, with the ACA primer, the STT reference strains produced a band of approximately $0.7 \mathrm{~kb}$, which was absent in the LTT reference strains and in the strains from the seedlings. With the CCA primer, only the LTT reference strains and the strains from the seedlings had a $1.5-\mathrm{kb}$ band.

The isolates of the Phomopsis sp. originating from diseased Norway spruce seedlings showed RAMS-ACA and RAMS-CCA banding patterns that were identical among the isolates (data not shown), and sequencing of the strains (DQ116550 and DQ445886 to DQ445890) revealed 99 to $100 \%$ sequence similarity to each other in the ITS1 and ITS2 regions. The sequenced isolates of the Phomopsis sp. from nursery-grown Norway spruce seedlings and the included reference strains of $P$. conorum, $P$. juniperivora, and Diaporthe conorum (anamorph $P$. occulta) differed in the ITS1 and ITS2 regions. The two strains of D. conorum (DQ116551 and DQ116552) from the CBS culture collection showed 90\% sequence similarity to each other and $91 \%$ sequence similarity to

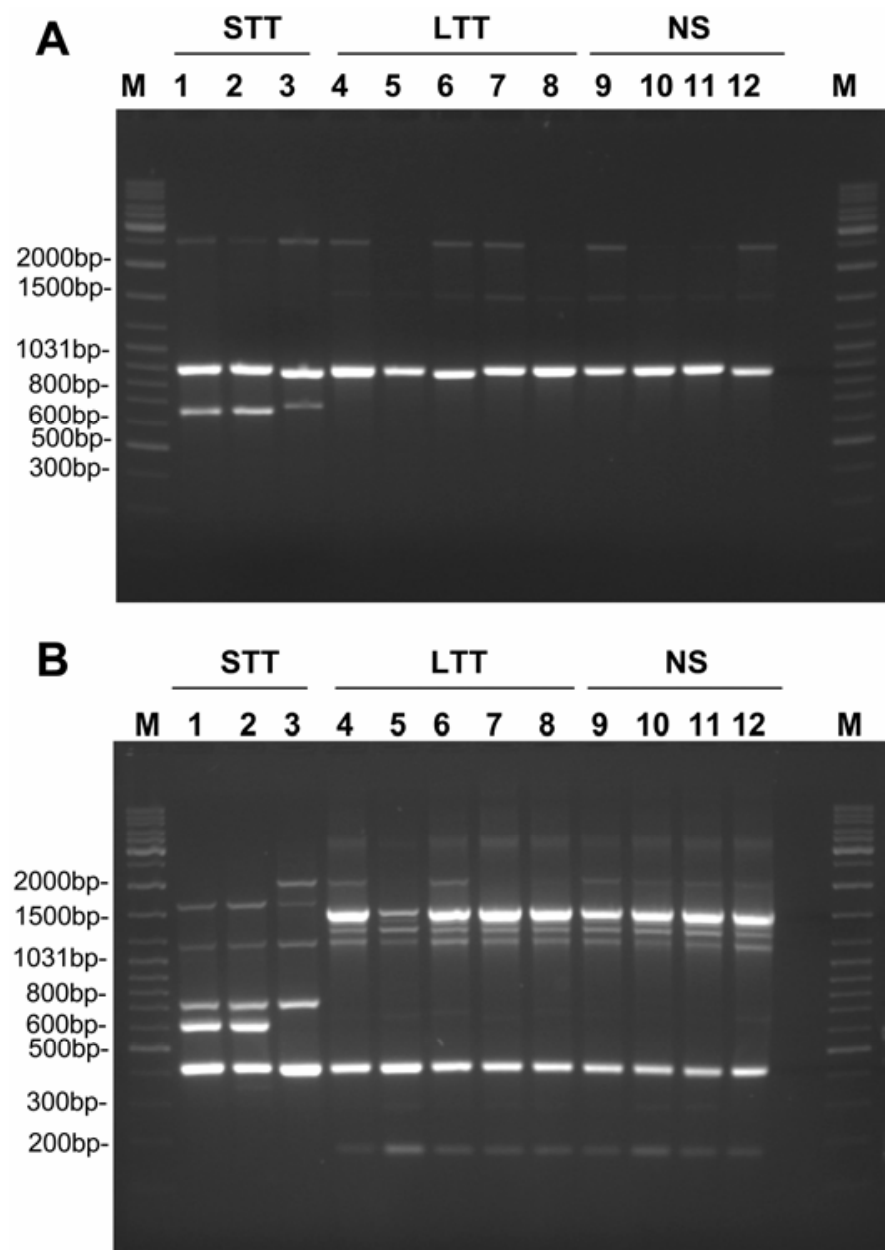

Fig. 4. Random amplified microsatellite (RAMS) patterns obtained from small-tree-type (STT) and large-tree-type (LTT) Gremmeniella abietina using the A, ACA and B, CCA primer sets. Obtained RAMS patterns of three STT $(1988-306 / 1,1988-307 / 3$, and 1974-46/1) G. abietina reference strains, five LTT (2002-20/4, 2002-47/1, 1985-111/6, 1985-393/16/1, and 1966-163/2) G. abietina reference strains, and four isolates (2002-4/4, 2002-79/2, 2002$107 / 2$, and 2002-124/1) obtained from diseased Norway spruce seedlings from Norwegian nurseries (NS) with Gremmeniella problems. Lane M: DNA size marker (GeneRuler DNA ladder mix). 
the isolates of the Phomopsis sp. from Norway spruce seedlings. $P$. conorum (DQ116553) and P. juniperivora (DQ116555) showed 92 and $70 \%$ ITS sequence similarity, respectively, to our isolates of the Phomopsis sp. from Norway spruce seedlings over the region sequenced. In BLAST against the NCBI GenBank Sequence Databases, a previously sequenced $D$. phaseolorum (anamorph P. phaseoli), GenBank accession no. AF001027, isolated from diseased soybean, showed the highest ITS sequence similarity $(95 \%)$ to the isolates of the Phomopsis sp. recovered from Norway spruce seedlings.

Real-time PCR. The primer set developed for monitoring Norway spruce did not detect DNA of G. abietina and the Phomopsis sp. and the primer/probe sets used for detecting DNA of these fungi did not detect DNA of Norway spruce. In addition, these two sets did not detect DNA of $S$. conigenus, $B$. cinerea, $H$. juniperi, $R$. kalkhoffii, E. nigrum, $N$. fuckeliana, and T. parca when DNA $(1,000 \mathrm{pg})$ from these references was used as the template. Excluding $P$. juniperivora, the reference strains of $D$. conorum and $P$. conorum could be amplified in a SYBR Green assay with the primers for detecting the Phomopsis sp. However, none of these were detected when the probe-based real-time PCR assay we are reporting here was used. In the standard curve samples constructed for Norway spruce (Norway spruce DNA spiked with G. abietina and Phomopsis sp. DNA), there was a linear relationship between the $\mathrm{Ct}$ values and the logarithm of the amount of spruce DNA in the range of 100,000 to $100 \mathrm{pg}$ of host DNA. In the standard curve for samples constructed for G. abietina (Gremmeniella DNA spiked with Norway spruce and Phomopsis DNA) and the Phomopsis sp. (Phomopsis DNA spiked with Norway spruce and Gremmeniella DNA), there was a linear relationship between the $\mathrm{Ct}$ values and the logarithm of the amount of DNA in the range of 1,000 to $0.1 \mathrm{pg}$ of pathogen DNA, showing that the assays can be used for quantitative monitoring of the fungi in a broad range of colonization. The standard curves were constructed based on the relationship of $\mathrm{Ct}$ values $(x)$ and the amount of template $(y)$ generated from known host and pathogen DNA concentrations: Norway spruce, G. abietina, and the Phomopsis sp. DNA amount standard curves were $\log y=11.45-0.280 x$ $\left(R^{2}=0.999, P<0.0001\right), \log y=8.74-0.280 x\left(R^{2}=0.999, P<\right.$ $0.0001)$, and $\log y=8.47-0.272 x\left(R^{2}=0.999, P<0.0001\right)$, respectively (Fig. 5).

Approximately 100 Norway spruce seedlings with necrotic stem lesions, collected in the years 2003 and 2004 from the nurseries in southeastern Norway with disease problems in 2002, were screened for the presence of G. abietina and a Phomopsis $\mathrm{sp}$. The differences in the host and pathogen $\mathrm{Ct}$ values between 10- and 100-fold diluted DNA samples from the seedlings were in the ranges (3.3 to 3.6 ) observed in the corresponding log-diluted standard curves as well (data not shown). This indicates that the diluted DNA samples from seedlings did not contain any substances inhibitory to PCR amplification, and that the assays were not saturated with the template levels present in the diluted DNA samples from seedlings. Thus, the $\mathrm{Ct}$ values from 10 -fold-diluted DNA samples were used to calculate the amount of host and pathogen DNA in the seedlings. More than $80 \%$ of the seedlings with necrotic stem lesions hosted a Phomopsis sp., whereas DNA of G. abietina was detected in only one seedling. In both cases, the host DNA yield was low in the samples taken from the middle and from the margin of a necrotic lesion, whereas samples taken outside the lesions had host DNA yields comparable with the healthy control stems (Table 3). For the Phomopsis sp., the pathogen/host DNA amount ratio showed a gradient within the lesion, the highest levels of the pathogen colonization being in the middle of the lesion. We also spiked DNA obtained from selected infected and healthy seedlings to further test the function of the assays. Close to $100 \%$ of the added G. abietina or Phomopsis sp. DNA was detected in all samples that were diluted similarly (10-fold) to the experimental samples (Table 3).

\section{DISCUSSION}

Most of the literature on nurseries reports G. abietina exclusively as a pathogen on pine seedlings and, if associated with Norway spruce, G. abietina is mentioned as a pathogen on sap-

\section{A Standard curve for Norway spruce}

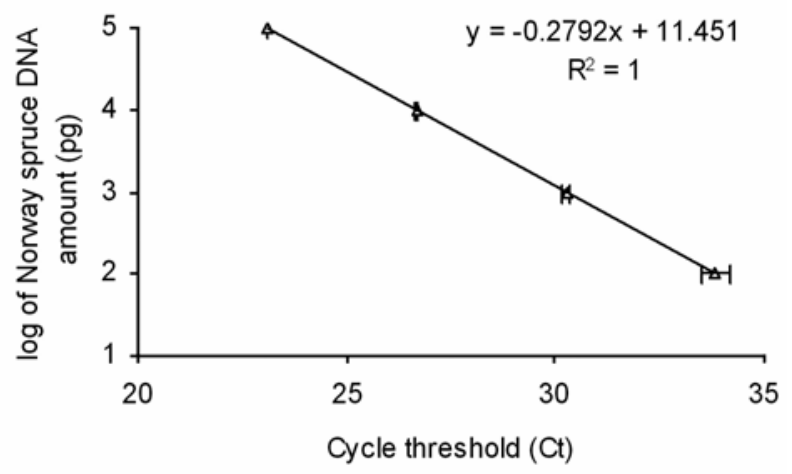

B Standard curve for Gremmeniella abietina

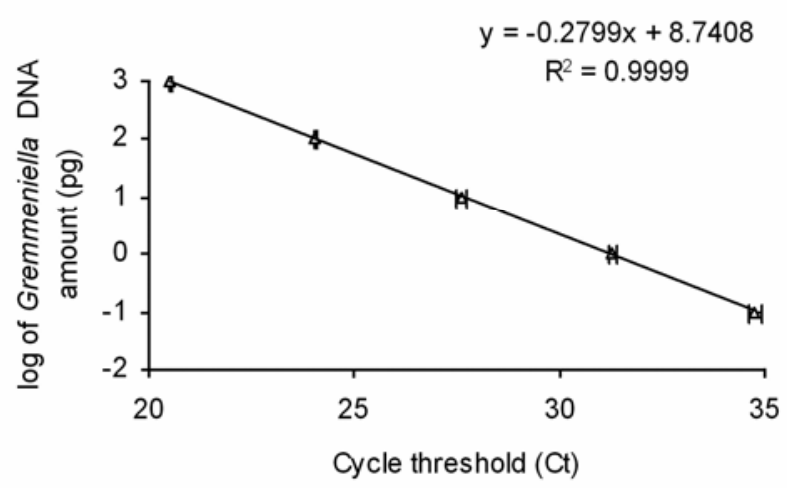

C Standard curve for Phomopsis sp.

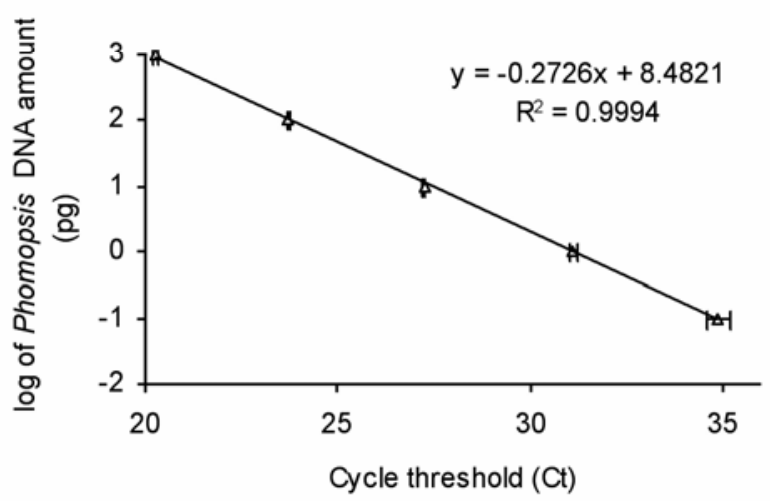

Fig. 5. Standard curves for quantifying the DNA amount of Norway spruce, Gremmeniella abietina, and a Phomopsis sp. Cycle threshold values were plotted against $\log 10$-transformed DNA amounts, and linear regression equations were calculated for the quantification of DNA pools by interpolation in unknown samples. A, The host DNA standard samples $(100,000,10,000$, 1,000 , and $100 \mathrm{pg}$ of Norway spruce DNA) all were spiked with $1,000 \mathrm{pg}$ of G. abietina and 1,000 pg of the Phomopsis sp. DNA. B, The G. abietina DNA standard curve samples $(1,000,100,10,1$, and $0.1 \mathrm{pg}$ of G. abietina DNA) all were spiked with $1,000 \mathrm{pg}$ of Norway spruce and 1,000 pg of Phomopsis sp. DNA. C, The Phomopsis DNA standard curve samples $(1,000,100,10,1$, and $0.1 \mathrm{pg}$ of Phomopsis sp. DNA) all were spiked with $1,000 \mathrm{pg}$ of Norway spruce and 1,000 pg of G. abietina DNA. Three polymerase chain reaction replicates were run on each sample. 
lings (18) and on larger seedlings in plantations (27). In pine seedlings, the disease is easily recognized by the characteristic umbrella-like folding of needles on the leader shoot $(4,22)$, whereas the symptoms of G. abietina infection in Norway spruce seedlings (necroses and shoot dieback) are rather nonspecific and may resemble symptoms caused by other pathogens (such as S. conigenus) as well as abiotic stresses, such as frost, drought, or cold storage. Because multiple factors can cause these symptoms in Norway spruce seedlings, the incidents of G. abietina infection easily may be misidentified, especially during nonepidemic periods when the infection origin is less obvious.

The inoculation tests performed with the strains examined here resulted in necroses and confirmed the pathogenicity of the fungus on Norway spruce seedlings. By simulating the bark fissure infection in the pathogenicity tests carried out with seedlings, we reproduced bark necroses by G. abietina inoculation. The symptoms of shoot dieback were not reproduced due to the short duration of our in vivo experiment, caused by a technical problem. In the Norway spruce nurseries affected by G. abietina, stem necroses became visible after wintering or planting out in 2002, a year after the infection. The timing of symptom appearance agrees with observations of Barklund and Unestam (3), who reported that, in artificially inoculated Norway spruce seedlings, a latent stage occurs in summer and fall, during which the fungus colonizes only the outer stem tissues. During the winter, the fungus actively colonizes the inner stem tissues and the symptoms develop during the following spring or summer (3). Due to this long latent stage, seedlings infected by G. abietina can be planted out before the symptoms develop in the nursery. Our conclusion is that the incidence of G. abietina on nursery-grown Norway spruce seedlings probably is not new but simply has been overlooked due to the long latent development, nonspecific symptoms, and sparse occurrence during nonepidemic periods.

Hamelin and Rail (12) analyzed the ITS sequence of a number of G. abietina var. abietina strains obtained from different pine species and showed that the ITS sequences were identical for all members of the European race, and that the European race differs from the North American race of G. abietina var. abietina at two nucleotides in this region. In the present study, ITS rDNA sequence analysis of the G. abietina strains isolated from necroses formed on nursery-grown Norway spruce seedlings indicated that the strains belonged to the European race of this $G$. abietina variety, because their ITS sequences were identical to those of the European-race strains reported by Hamelin and Rail (12).

To further characterize the G. abietina strains associated with Norway spruce seedlings, we employed RAMS analysis, a technique that provides ecotype-specific banding patterns (14). The RAMS banding patterns obtained from $G$. abietina strains isolated from Norway spruce seedlings were identical to each other and to those from the included reference strains representing the LTT, but differed from those of the STT. These data confirmed that the strains associated with nursery-grown Norway spruce seedlings belonged to the LTT of the European race. The presently studied nursery samples were collected from the geographical area in southeastern Norway where a devastating epidemic of G. abietina had occurred on Scots pine trees in the previous year. This epidemic was a typical LTT outbreak, characterized by dieback of shoots in the entire crown (29). All of the isolates of G. abietina from diseased nursery seedlings of Norway spruce were grouped in the LTT, suggesting that the unusual disease outburst on Norway spruce seedlings in 2002 likely was related to the previous year's epidemic on Scots pines. Apparently, similar damage in Norway spruce seedlings after the pine epidemic also was observed in Sweden (E. Stenström, personal communication) and in Finland (24).

G. abietina attack on spruce seedlings can be difficult to identify (no fruit bodies present, nonspecific disease symptoms, and causal pathogen often may be dead or inactive at the time of identification); therefore, we developed real-time PCR assays for detecting its presence and for monitoring the development of the

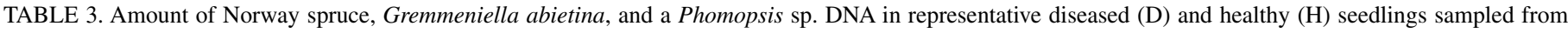
Gremmeniella-affected nurseries during the years 2003 to $2004^{\mathrm{a}}$

\begin{tabular}{|c|c|c|c|c|c|c|c|c|}
\hline \multirow[b]{2}{*}{ Seedling no. } & \multirow[b]{2}{*}{ Position $^{\mathrm{b}}$} & \multirow[b]{2}{*}{ DNA yield $(\mathrm{ng} / \mu \mathrm{l})$} & \multicolumn{2}{|c|}{ DNA amount ratio $(\%)$} & \multicolumn{2}{|c|}{ Recovery of DNA added (\%) } & \multirow[b]{2}{*}{ Condition } & \multirow[b]{2}{*}{ Nursery } \\
\hline & & & Gremmeniella/host & Phomopsis/host & G. abietina ${ }^{\mathrm{c}}$ & Phomopsis sp. ${ }^{\mathrm{c}}$ & & \\
\hline \multirow[t]{3}{*}{6} & Middle & 4 & 0.29 & 0 & No DNA added & Missing data & $\mathrm{D}$ & Gvarv \\
\hline & Margin & 8 & 2 & 0 & No DNA added & 99.7 & $\ldots$ & $\ldots$ \\
\hline & Outside & 130 & 0 & 0 & No DNA added & 104.5 & $\ldots$ & $\ldots$ \\
\hline \multirow[t]{3}{*}{38} & Middle & 0.5 & 0 & 0.53 & 99.9 & No DNA added & $\mathrm{D}$ & Gvarv \\
\hline & Margin & 22 & 0 & 0.41 & 100.8 & No DNA added & $\ldots$ & $\ldots$ \\
\hline & Outside & 160 & 0 & 0 & 95.2 & No DNA added & $\ldots$ & $\ldots$ \\
\hline \multirow{3}{*}{39} & Middle & 4 & 0 & 0.40 & 105.2 & No DNA added & $\mathrm{D}$ & Gvarv \\
\hline & Margin & 26 & 0 & 0.14 & 99.9 & No DNA added & $\ldots$ & $\ldots$ \\
\hline & Outside & 125 & 0 & 0 & 98.3 & No DNA added & $\ldots$ & $\ldots$ \\
\hline \multirow[t]{3}{*}{$55^{\mathrm{d}}$} & Middle & 9 & 0 & 0.47 & 125.5 & No DNA added & $\mathrm{D}$ & Prestebakke \\
\hline & Margin & 21 & 0 & 0.13 & 105.5 & No DNA added & $\ldots$ & $\ldots$ \\
\hline & Outside & 120 & 0 & 0 & 98.0 & No DNA added & $\ldots$ & $\ldots$ \\
\hline \multirow[t]{3}{*}{$57^{\mathrm{d}}$} & Middle & 20 & 0 & 0.34 & 99.2 & No DNA added & $\mathrm{D}$ & Prestebakke \\
\hline & Margin & 25 & 0 & 0.1 & 96.4 & No DNA added & $\ldots$ & $\ldots$ \\
\hline & Outside & 190 & 0 & 0 & 92.7 & No DNA added & $\ldots$ & $\ldots$ \\
\hline \multirow[t]{3}{*}{53} & Middle & 125 & 0 & 0 & 95.8 & 106.4 & $\mathrm{H}$ & Prestebakke \\
\hline & Margin & 97 & 0 & 0 & 94.2 & 112.7 & $\ldots$ & $\ldots$ \\
\hline & Outside & 153 & 0 & 0 & 94.2 & 104.9 & $\ldots$ & $\ldots$ \\
\hline \multirow[t]{3}{*}{43} & Middle & 123 & 0 & 0 & 95.8 & 100.4 & $\mathrm{H}$ & Gvarv \\
\hline & Margin & 148 & 0 & 0 & 93.3 & 102.3 & $\ldots$ & $\ldots$ \\
\hline & Outside & 70 & 0 & 0 & 96.7 & 106.4 & $\ldots$ & $\ldots$ \\
\hline
\end{tabular}

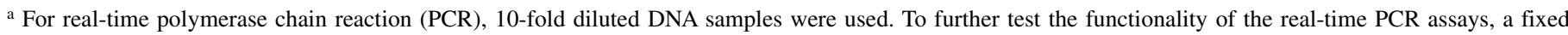
amount of G. abietina or Phomopsis sp. DNA was added to selected samples.

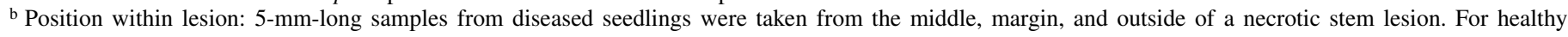
seedlings, the 5-mm-long samples were taken next to each other.

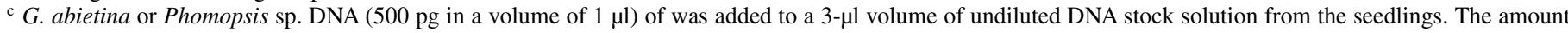
of the added DNA was quantified by real-time PCR in 10-fold diluted samples by using a 4- $\mu$ l-volume template. The recovery was estimated from the obtained critical threshold values by using the standard curve equation generated for the corresponding pathogen. A value of $100 \%$ indicates that 50 pg of the added DNA was detected in the 10-fold diluted sample.

$\mathrm{d}$ The presence of a Phomopsis sp. within the lesion also was confirmed by fungal isolation. 
disease in the affected nurseries after the problematic year 2002. Specificity of assays used for quantifying a pathogen under field conditions is crucial, so that coexisting microbes can be excluded. The primer/probe sets used here for monitoring G. abietina and a Phomopsis sp. did not detect the included reference ascomycetes, species that can be commonly associated with diseased shoots of Norway spruce seedlings. The different species and varieties of Gremmeniella are very similar but not identical in the ITS regions. In the annealing sites of the forward primer, probe, and reverse primer used here for monitoring G. abietina, var. abietina differs from var. balsamea in one, one, and seven nucleotides, respectively (data not shown). G. abietina var. abietina is the only Gremmeniella sp. or G. abietina variety occurring on spruce in Europe (26). However, should the developed primer/probe set be used for monitoring G. abietina var. abietina in hosts or areas where several varieties or species of Gremmeniella can coexist, further specificity tests need to be performed. For example, both G. abietina var. abietina and G. laricina can infect Larix spp., whereas G. abietina var. balsamea, the variety known only from Quebec, Canada, can infect Picea glauca and P. mariana in addition to A. balsamea (25). The high specificity of the Phomopsis primer/probe used was confirmed, because the assay did not detect $D$. conorum (anamorph Phomopsis occulta) and P. conorum, species closely related to the investigated Phomopsis sp. but also commonly present in diseased shoots of Norway spruce $(6,8)$.

Although a Phomopsis sp. commonly was detected in necrotic lesions of seedlings collected during the years 2003 and 2004 ( 2 and 3 years after the G. abietina epidemic, respectively), G. abietina was detected in only 1 of the 100 seedlings examined. The good recovery of the added G. abietina and Phomopsis DNA from DNA obtained from infected seedlings in the spiking test indicates that the monitoring data obtained from the sampled seedlings were reliable. Therefore, the absence of G. abietina in the real-time PCR screening indicates a rapid decline in the $G$. abietina population in the nurseries after the epidemic outbreak in 2001, which is in agreement with the absence of similar epidemics in the nearby forests during the two monitored years. That Scots pine forests near the nurseries were the most possible source of inoculum, a fact reflected in the observation that G. abietina was recovered most often from seedlings originating from the nursery having large pines in the vicinity, whereas isolations from seedlings originating from nurseries with no pines nearby resulted in no G. abietina being found.

In addition to $G$. abietina, a Phomopsis sp. frequently was associated with the shoot dieback or stem necrosis symptoms in the Norway spruce seedlings examined. However, whereas G. abietina strains were recovered from cankers formed on the upper part of the stem, Phomopsis sp. was obtained primarily from cankers formed on the lower part of the stem. Compatible with our observations, Hansen and Hamm (13) report on Phomopsis spp. associated with top-kill symptoms of Douglas fir seedlings, where necroses were formed at the base of new shoots. They suggested that the infection takes place during the summer, possibly through the bud scales. In addition to location, the appearance of necroses associated with G. abietina and the Phomopsis sp. also differed. Resin flow, a characteristic conifer response upon pathogen attack, commonly was observed in necroses hosting G. abietina, whereas Phomopsis sp.-associated necroses were water soaked and without any resin flow. Moreover, necrotic spots and shriveling of needle tissue was characteristic on needles infected by G. abietina in the needle bioassay, whereas needles overgrown by the Phomopsis sp. showed a uniform discoloration, with needles remaining turgid. These data suggest that the fungi differ in their mode of interaction with the host tissue.

Based on the ITS rDNA sequence analysis performed, the Phomopsis isolates did not represent any previously characterized Phomopsis sp. associated with conifers, because the included reference strains of D. conorum (anamorph $P$. occulta), P. conorum, and $P$. juniperivora showed relatively low sequence similarities to the isolates of the Phomopsis sp. from Norway spruce seedlings. In the deposits of the NCBI GenBank Sequence Database, our isolates of the Phomopsis sp. had the highest sequence similarity (95\%) with D. phaseolorum, a pathogen causing stem cankers near the stem node on soybean (9). The ITS sequence similarity of the isolates of the Phomopsis sp. from Norway spruce seedlings to deposits at the NCBI GenBank Sequence Database also was relatively low ( $\leq 95 \%$ ); therefore, it is likely that the Phomopsis sp. strains here studied represent an as yet uncharacterized species. This complicates comparison with other studies. Bearing this warning in mind, $P$. occulta has been associated with stem cankers $(8,11)$, while $P$. conorum has been observed in shoot dieback of young spruce trees in Austria $(6,8)$. Cech (T. Cech, personal communication) confirms the occurrence of Phomopsis spp. on spruce, but has the opinion that the genus Phomopsis is a secondary fungus, infecting after (for example) Sirococcus or Gremmeniella spp. Similarly, Perny et al. (23) also described Phomopsis spp. as merely weak parasites of spruce that are favored only in cases of adverse climatic conditions, wrong provenance, or localization. Our data are consistent with the latter two cases because, in the included pathogenicity tests, the Phomopsis sp. strains showed low pathogenicity. Our current hypothesis is that, in order to become pathogenic, the presently examined Phomopsis sp. strains need specific host-predisposing conditions, such as infection by other pathogens or abiotic stress.

In conclusion, disease symptoms caused by G. abietina in nursery-grown Norway spruce seedlings are reported here for the first time. The incidence of the disease on Norway spruce seedlings was observed 1 year after a severe G. abietina var. abietina epidemic on Scots pine trees and likely was related to this. The absence of the pathogen in Norway spruce seedlings in the affected nurseries during the two monitored years after the epidemic indicates that, as in pine seedlings, the disease is not a problem in Norway spruce seedlings during nonepidemic years. Removal of the Scots pine trees, a source of G. abietina inoculum, from the immediate vicinity of the nursery may diminish the damage to seedlings. The developed real-time PCR assay makes it possible to monitor the presence of G. abietina var. abietina in nursery seedlings during the early, latent asymptomatic stage of this disease, but this tool also can be employed to monitor G. abietina in the nearby forests. In years with high infection pressure of G. abietina, selective chemical treatment of Scots pine and also Norway spruce seedlings seems warranted. We report here on a Phomopsis sp. associated with lower-stem necroses in Norway spruce seedlings; however, the pathogenicity potential and function of this fungus is still unclear.

\section{ACKNOWLEDGMENTS}

This study was financed and supported by the Department of Food and Agriculture, the Development Fund for Forestry and the Norwegian Forest and Landscape Institute. We thank O. Olsen, I. Heldal, and L. Ljevo for their excellent technical assistance and M. Andersen for his valuable field experience.

\section{LITERATURE CITED}

1. Barklund, P., and Hellgren, M. 1992. Skadesvampen Gremmeniella abietina på tall och gran. Skogsfakta 16. (In Swedish)

2. Barklund, P., and Rowe, J. 1981. Gremmeniella abietina (Scleroderris lagerbergii), primary parasite in a Norway spruce dieback. Eur. J. For. Pathol. 11:97-108.

3. Barklund, P., and Unestam, T. 1988. Infection experiments with Gremmeniella abietina on seedlings of Norway spruce and Scots pine. Eur. J. For. Pathol. 18:409-420.

4. Björkman, E. 1959. Ny svampsjukdom i skogträdsplantskolor. Skogen 46:292-293. (In Swedish)

5. Butin, H. 1995. Tree Diseases and Disorders. Oxford University Press, Oxford. 
6. Cech, T., and Perny, B. 1995. Über Pucciniastrum areolatum (Alb. et Schw.) Liro (Uredinales) und andere Mikropilze im Zusammenhang mit Wipfelschäden an Jungfichten (Picea abies (L.) Karst.). Forstl. Bundesversuchsanst. Wien Mitt. 88:5-27.

7. Donaubauer, E. 1972. Environmental factors influencing outbreak of Scleroderris lagerbergii Gremmen. Eur. J. For. Pathol. 2:21-25.

8. Donaubauer, E. 1995. Über die Phomopsis-Krankheit bei Fichten (Picea abies (L.) Karst.). Forstl. Bundesversuchsanst. Wien Mitt. 88:29-32.

9. Fernandez, F. A., and Hanlin, R. T. 1996. Morphological and RAPD analyses of Diaporthe phaseolorum from soybean. Mycologia 88:425-440.

10. Galaaen, R., and Venn, K. 1979. Effects of benomyl on 2-0 seedlings of Picea abies (L.) Karst. Rep. Norw. For. Res. Inst. 34.11.

11. Hahn, G. G. 1943. Taxonomy, distribution, and pathology of Phomopsis occulta and P. juniperivora. Mycologia 35:112-129.

12. Hamelin, R. C., and Rail, J. 1997. Phylogeny of Gremmeniella spp. based on sequences of the 5.8S rDNA and internal transcribed spacer region. Can. J. Bot. 75:693-698.

13. Hansen, E. M., and Hamm, P. B. 1988. Canker diseases of Douglas-fir seedlings in Oregon and Washington bareroot nurseries. Can. J. For. Res. 18:1053-1058.

14. Hantula, J., and Müller, M. M. 1997. Variation within Gremmeniella abietina in Finland and other countries as determined by random amplified microsatellites (RAMS). Mycol. Res. 101:169-175.

15. Hellgren, M., and Barklund, P. 1992. Studies of the life cycle of Gremmeniella abietina on Scots pine in southern Sweden. Eur. J. For. Pathol. 22:300-311.

16. Hellgren, M., and Högberg, N. 1995. Ecotypic variation of Gremmeniella abietina in northern Europe: Disease patterns reflected by DNA variation. Can. J. Bot. 73:1531-1539.

17. Hietala, A. M., Eikenes, M., Kvaalen, H., Solheim, H., and Fossdal, C. G. 2003. Multiplex real-time PCR for monitoring Heterobasidion annosum colonization in Norway spruce clones that differ in disease resistance. Appl. Environ. Microbiol. 69:4413-4420.

18. Kaitera, J., Seitamäki, L., and Jalkanen, R. 2000. Morphological and ecological variation of Gremmeniella abietina var. abietina in Pinus sylvestris, Pinus contorta and Picea abies sapling stands in northern Finland and the Kola Peninsula. Scand. J. For. Res. 15:13-19.

19. Karlman, M., Hansson, P., and Witzell, J. 1994. Scleroderris canker on lodgepole pine introduced in northern Sweden. Can. J. For. Res. 24:19481959.

20. Lagerberg, T. 1913. Granens topptorka. Sven. Skogvårdsfören. Tidskr.
173-208. (In Swedish)

21. Marosy, M., Patton, R. F., and Upper, C. D. 1989. A conducive day concept to explain the effect of low temperature on the development of Scleroderris shoot blight. Phytopathology 79:1293-1301.

22. Nef, L., and Perrin, R. 1999. Practical handbook on damaging agents in the European forest nurseries. EU, Air 2-CT93-1694 project. European Communities, Luxembourg.

23. Perny, B., Cech, T., Donaubauer, E., and Tomiczek, C. 2002. Krankheiten und Schädlinge in Christbaumkulturen. BFW, Institut für Forstschutz, Wien, Germany.

24. Petäistö, R.-L. 2003. Surmakkatuhoja esiintyi kevälllä. Pages 8-11 in: Taimi uutiset 2. Suonenjoen tutkimusasema. (In Finnish)

25. Petrini, O., Petrini, L. E., LaFlamme, G., and Ouellette, G. B. 1989. Taxonomic position of Gremmeniella abietina and related species: A reappraisal. Can. J. Bot. 67:2805-2814.

26. Petrini, O., Toti, L., and Petrini, L. E. 1990. Gremmeniella abietina and G. laricina in Europe: Characterization and identification of isolates and laboratory strains by soluble protein electrophoresis. Can. J. Bot. 68:2629-2635.

27. Roll-Hansen, F. 1967. On diseases and pathogens on forest trees in Norway 1960-1965. Medd. Nor. Skogfors øksves. 21:178-246.

28. Solheim, H. 1986. Toppdød på gran. Nor. Skogbruk 32(6/7):12-14. (In Norwegian)

29. Solheim, H. 2001. Mye brun furu i Sørøst-Norge i år. Pages 9-11 in: Kontaktkonferansen mellom skogbruket og skogforskningen i Telemark og Aust-Agder. S. Woxholtt, ed. Drangedal 19-21 September 2001. Aktuelt fra Skogforskningen 6/01. (In Norwegian)

30. Uotila, A.1983. Physiological and morphological variation among Finnish Gremmeniella abietina isolates. Commun. Inst. For. Fenn. 119.

31. Uotila, A. 1992. Mating system and apothecia production in Gremmeniella abietina. Eur. J. For. Pathol. 22:410-417.

32. Uotila, A., Hantula, J., Väätänen, A. K., and Hamelin, R. C. 2000. Hybridization between two biotypes of Gremmeniella abietina var. abietina in artificial pairings. Eur. J. For. Pathol. 30:211-219.

33. White, T. J., Bruns, T., Lee, S., and Taylor, J. 1990. Amplification and direct sequencing of fungal ribosomal RNA genes for phylogenetics. Pages 315-322 in: PCR Protocols. A Guide to Methods and Applications. M. A. Innis, D. H. Gelfand, J. J. Sninsky, and T. J. White, eds. Academic Press, San Diego, CA

34. Wilson, I. G. 1997. Inhibition and facilitation of nucleic acid amplification. Appl. Environ. Microbiol. 63:3741-3751. 